\title{
TEORI NARATOLOGI GÉRARD GENETTE (TINJAUAN KONSEPTUAL)
}

\author{
Herman Didipu \\ Universitas Negeri Gorontalo \\ Jalan Jend. Sudirman No.6, Dulalowo Timur, Kota Tengah \\ Kota Gorontalo, Gorontalo, Indonesia \\ herdi.ung@gmail.com
}

\begin{abstract}
Abstrak
Artikel ini bertujuan menguraikan pokok pemikiran konseptual teori naratologi Gérard Genette. Pokok pemikiran teori naratologi Gérard Genette dituangkan dalam bukunya yang berjudul Narrative Discourse: An Essay in Method. Genette mengusulkan untuk menggunakan tiga istilah yang berbeda. Pertama, kata story 'cerita' yang menjadi signified 'petanda' atau konten narasi. Istilah story ini sepadan dengan kata histoire (Prancis) dan geschichte (Jerman). Kedua, kata narrative 'naratif atau penceritaan' sebagai signifier atau penanda, pernyataan, wacana atau sebagai teks naratif itu sendiri. Istilah narrative sejajar dengan kata récit (Prancis) dan discourse (Inggris). Ketiga, istilah narrating 'menceritakan'sebagai aksi atau tindakan memproduksi naratif, atau dalam pengertian yang lebih luas, sebagai keseluruhan situasi nyata atau fiksi di mana aksi terjadi. Genette mengemukakan tiga kategori struktur naratif sebagai dasar pemikirannya, yaitu tense, mood, dan voice. Dalam pembahasan bukunya, selanjutnya Genette membagi unsur tense menjadi tiga bagian, yaitu order, duration, dan frequency. Dengan demikian, pokok bahasan struktur naratif/penceritaan Gérard Genette terdiri atas lima kategori utama, yaitu (1) urutan naratif (order), (2) durasi naratif (duration), (3) frekuensi naratif (frequency), (4) modus naratif (mood), dan (5) suara naratif (voice).
\end{abstract}

Kata kunci: naratologi, Gérard Genette, urutan, durasi, frekuensi, modus, suara naratif

\section{Gérard Genette Narratology Theory (Conceptual Review)}

\begin{abstract}
This article aims to describe the main conceptual thinking of the narratology theory of Gerard Genette. The main idea of the Gérard Genette narratology theory is outlined in his book entitled Narrative Discourse: An Essay in Method. Genette proposed to use three different terms. First, said the 'story' which became signified or narrative content. The term story is commensurate with the words histoire (French) and geschichte (Germany). Second, the narrative word as a signifier, statement, discourse or narrative text itself. The term narrative is parallel to the word récit (French) and discourse (English). Third, the term narrating as an action or action to produce a narrative, or in a broader sense, as a whole real situation or fiction where the action takes place. Genette presents three categories of narrative structure as the basis for thinking, namely tense, mood, and voice. In the discussion of his book, Genette then divides tense elements into three parts, namely order, duration, and frequency. Thus, the subject matter of the Gérard Genette narrative structure consists of five main categories, namely (1) order, (2) duration, (3) frequency, (4) mood, and (5) voice.
\end{abstract} Keywords: narratology, Gérard Genette, order, duration, frequency, mood, voice

\section{PENDAHULUAN}

Naratologi merupakan salah satu teori yang digunakan dalam kajian atau kritik sastra. Istilah "naratologi" (narratology) secara global digunakan sebagai padanan dari istilah "teori naratif" (narrative theory), yang merujuk pada studi naratif sebagai genre (Fludernik, 2009: 8). Prince (1982: 4) mengartikan naratologi sebagai studi tentang bentuk dan fungsi naratif. Jannidis (2003: 36) mendefinisikan naratologi sebagai studi tentang bagaimana berbicara dan berpikir direproduksi dalam teks-teks naratif.
Sementara itu, Bortolussi dan Dixon (2003:10) menyatakan bahwa naratologi merupakan studi yang pada dasarnya berkaitan dengan identifikasi dan deskripsi teoretis karakteristik formal teks naratif.

Dalam perkembangannya, pokok teori dan metodologi kajian naratologi cukup bervariasi sesuai dengan pakar atau ahli yang mengembangkannya. Salah satu ahli atau pakar yang mengembangkan teori naratologi adalah Gérard Genette. Gérard Genette merupakan salah seorang pakar pengembang teori naratologi berkebangsaan Prancis. Kontribusi 
terbesar Genette terhadap teori naratologi tertuang dalam bukunya yang berjudul Discours du Récit yang terbit pertama kali dalam bahasa Prancis pada tahun 1972, kemudian diterjemahkan ke dalam bahasa Inggris Narrative Discourse: An Essay in Method oleh Jane E. Lewin pada tahun 1980.

Gérard Genette menjadi tokoh penting dalam pengembangan teori naratologi, khususnya yang telah digagas oleh para tokoh Formalisme Rusia seperti Vladimir Propp, serta pakar naratologi asal Prancis yaitu Tzvetan Todorov. Genette memberikan kontribusi yang brilian terhadap teori naratologi, demikian dinyatakan oleh Bertens (2014: 60). Perbedaan mendasar antara Genette dengan Propp maupun Todorov adalah pada pengamatan mereka terhadap konstruksi sebuah naratif. Propp dan Todorov membagi atas dua bagian besar naratif, yaitu "cerita" dan "plot". Para Formalisme Rusia seperti Propp menyebut istilah "cerita" dan "plot" dengan fabula dan sjužet (bahasa Rusia), sedangkan Todorov menyebutnya dengan histoire dan discours (bahasa Prancis). Berbeda dengan Genette yang melihat konstruksi naratif (dalam bahasa Prancis disebut récit) atas tiga makna. Genette (1980:27) mengusulkan untuk menggunakan tiga istilah yang berbeda. Pertama, kata story 'cerita' yang menjadi signified 'petanda' atau konten narasi. Istilah story ini sepadan dengan kata histoire (Prancis) dan geschichte (Jerman). Kedua, kata narrative 'naratif atau penceritaan' sebagai signifier atau penanda, pernyataan, wacana atau sebagai teks naratif itu sendiri. Istilah narrative sejajar dengan kata récit (Prancis) dan discourse (Inggris). Ketiga, istilah narrating 'menceritakan'sebagai aksi atau tindakan memproduksi naratif, atau dalam pengertian yang lebih luas, sebagai keseluruhan situasi nyata atau fiksi di mana aksi terjadi. Dari ketiga makna naratif tersebut, yang menjadi pokok kajian Genette adalah pada makna kedua, yaitu pada tingkat wacana naratif (narrative discourse). Tingkat wacana naratif menjadi pokok kajian Genette karena mempunyai cakupan yang lebih luas sebagai analisis tekstual (textual analysis) sehingga tepat dijadikan sebagai alat untuk mengkaji naratif sastra, khususnya naratif fiksi.

\section{PEMBAHASAN}

\section{Konsep dan Karakteristik Naratif}

Sebelum masuk pada berbagai konsep teori naratologi Gérard Genette, ada baiknya dibahas terlebih dahulu beberapa konsep dasar tentang "naratif" menurut beberapa pakar. Hal ini dimaksudkan agar tampak jelas perbedaan perspektif teori naratif Genette dengan pakar-pakar lainnya.

Chatman (1980: 19), dengan mengacu pada teori para strukturalis, melihat dua bagian pokok dari sebuah naratif, yaitu adanya (1) sebuah cerita atau story (histoire), yaitu isi atau rangkaian peristiwa (tindakan, kejadian), ditambah dengan apa yang disebut existents (karakter, dan hal-hal yang berhubungan dengan latar); serta (2) wacana (discours), yaitu ekspresi, yang menjadi sarana dalam mengkomunikasikan isi cerita. Sederhananya, cerita atau story adalah apa yang dinarasikan atau apa yang digambarkan, sedangkan wacana merupakan bagaimana cara menarasikan. Kedua istilah ini sejajar dengan istilah yang digunakan oleh kaum Formalis Rusia, yaitu fabula, atau hal-hal dasar cerita, jumlah total dari peristiwa yang akan terkait dalam narasi, dan sebaliknya sjuzet, cerita yang secara nyata berkisah dengan menghubungkan kejadian secara bersama-sama.

Prince (1982:1) menyatakan bahwa naratif adalah representasi dari berbagai peristiwa dan situasi nyata maupun fiktif dalam urutan waktu. Prince menekankan arti penting dimensi waktu (dimension of time) dalam sebuah naratif. Konsep dimensi waktu yang terdapat dalam sebuah kisah akan menentukan sebuah representasi adalah naratif atau bukan. Jika 
sebuah teks terdapat urutan waktu, teks tersebut merupakan naratif. Sebagai contoh, kalimat "John sangat kaya maka ia mulai berjudi dan ia menjadi sangat miskin", merupakan naratif karena di dalamnya ada urutan waktu. Kalimat "Ada perkelahian kemarin" maupun "Ini adalah perjalanan yang indah" bukanlah merupakan naratif karena keduanya tidak merepresentasikan rangkaian peristiwa, namun hanya sebagai salah satu peristiwa.

Abbot (2002: 12) berpendapat bahwa naratif adalah representasi dari sebuah peristiwa atau rangkaian dari peristiwa. Abbot lebih menekankan konsep "peristiwa" (event) sebagai kata kunci dalam sebuah naratif. Sebagian pakar menggunakan kata "tindakan" (action). Tanpa suatu peristiwa atau tindakan, itu mungkin hanya sebuah "deskripsi," "eksposisi," "argumen," "lirik," atau yang lainnya. Misalnya, kalimat "Anjing saya berkutu" hanyalah merupakan deskripsi tentang anjing saya, dan bukan merupakan naratif karena tidak ada yang terjadi. Berbeda dengan kalimat "Anjing saya digigit kutu" yang merupakan naratif, karena di dalamnya menceritakan suatu peristiwa. Peristiwanya mungkin sangat kecil --gigitan kutu--, tetapi itu cukup untuk membuat kalimat itu menjadi sebuah naratif.

Schmid (2010: 2) berpandangan bahwa naratif mengacu pada representasi yang di dalamnya terdapat perubahan keadaan (atau situasi). Berbeda dengan para pakar sebelumnya, Schmid lebih menekankan konsep perubahan keadaan (change of state) sebagai indikator utama sebuah naratif. Keadaan yang dimaksud adalah seperangkat sifat yang berkaitan dengan sesuatu yang diwakili atau situasi eksternal pada titik tertentu dalam waktu. Kita dapat membedakan keadaan internal dan eksternal atas dasar apakah sifat yang diwakili terkait dengan kehidupan batin dari yang diwakili atau unsur-unsur situasi eksternal. Sebagai contoh, kalimat "Raja meninggal dan kemudian ratu meninggal" merupakan naratif. Perubahan keadaan mereka tidak perlu secara eksplisit direpresentasikan. Kalimat tersebut menunjukkan perubahan keadaan tersirat, melalui representasi dua keadaan yang saling kontras.

Currie (2010: 1) menyatakan bahwa naratif adalah produk perantara, yang dijadikan sebagai sarana komunikasi cerita seseorang kepada orang lain. Naratif tidak lain merupakan artefak representasional yaitu sesuatu yang dibuat untuk menceritakan sebuah kisah, dengan cara merepresentasikan peristiwa cerita dan tokoh-tokoh. Naratif menceritakan berbagai hal dengan menyediakan representasi orang dan tindakan, benda dan kejadian. Walaupun terkadang yang disajikan dalam naratif bukanlah sebuah kebenaran, misalnya naratif fiksi, namun kita bisa memahami dan menerima bahwa isi cerita dalam naratif merupakan representasi dari kebenaran.

Pandangan lain tentang naratif seperti dikemukakan oleh Altman. Menurut Altman (2008:10-15), terdapat dua ciri utama dalam sebuah naratif yaitu tindakan (action) dan karakter (character). Narasi memerlukan tindakan. Sebuah telepon, mobil, dan detektif tidak menghasilkan narasi sampai mereka digerakkan oleh serangkaian tindakan: telepon berdering, detektif menjawab, kemudian melompat di dalam mobil. Narasi membutuhkan hadirnya karakter. Karakter merujuk pada tokoh/aktor dan juga sifat dari tokoh tersebut. Eksistensi naratif tergantung pada kehadiran secara bersama-sama dan terkoordinasi antara tindakan (action) dan karakter (character).

Berdasarkan pandangan beberapa pakar di atas, dapat ditarik beberapa karakteristik tentang naratif (narrative). Pertama, naratif merupakan representasi peristiwa fakta atau fiktif dalam bentuk cerita. Kedua, peristiwa itu harus dibangun dalam urutan waktu. Ketiga, naratif harus menampakkan perubahan baik secara implisit maupun eksplisit. Keempat, naratif merupakan sarana komunikasi. Kelima, naratif memerlukan kehadiran 
tindakan/aksi dan karakter.Dengan demikian, dapat disimpulkan bahwa naratif (narrative) adalah representasi peristiwa nyata atau fiktif yang di dalamnya terdapat perubahan keadaan atau situasi yang dibangun berdasarkan urutan waktu melalui tindakan dan karakter sebagai sarana komunikasi cerita seseorang kepada orang lain.

\section{Konsep Teori Naratologi Gérard Genette}

Berbeda dengan para pakar teori naratif lain, Genette membedakan tiga pengertian makna kata récit dalam bahasa Prancis, yang diterjemahkan narrative dalam Bahasa Inggris, dan 'naratif' atau 'penceritaan' dalam Bahasa Indonesia. Pertama, naratif sebagai pernyataan wacana naratif, baik secara lisan atau tertulis, untuk menceritakan suatu peristiwa atau serangkaian peristiwa. Kedua, naratif sebagai rangkaian peristiwa, nyata atau fiktif, yang merupakan pokok wacana, beserta segenap hubungan pertalian (linking), pertentangan (opposition), pengulangan (repetition), dan lain-lain. Ketiga, naratif merujuk pada cara sebuah peristiwa diceritakan, termasuk tindakan seseorang dalam menceritakan ceritanya sendiri (1980: 25--26).

Atas perbedaan makna naratif di atas, Genette (1980: 27) mengusulkan untuk menggunakan tiga istilah yang berbeda. Pertama, kata story 'cerita' yang menjadi signified 'petanda' atau konten narasi. Istilah story ini sepadan dengan kata histoire (Prancis) dan geschichte (Jerman). Kedua, kata narrative 'naratif atau penceritaan' sebagai signifier atau penanda, pernyataan, wacana atau sebagai teks naratif itu sendiri. Istilah narrative sejajar dengan kata récit (Prancis) dan discourse (Inggris). Ketiga, istilah narrating 'menceritakan' sebagai aksi atau tindakan memproduksi naratif, atau dalam pengertian yang lebih luas, sebagai keseluruhan situasi nyata atau fiksi di mana aksi terjadi. Dari ketiga makna naratif tersebut, yang menjadi pokok kajian Genette adalah pada makna kedua, yaitu pada tingkat wacana naratif (narrative discourse). Tingkat wacana naratif menjadi pokok kajian Genette karena mempunyai cakupan yang lebih luas sebagai analisis tekstual (textual analysis) sehingga tepat dijadikan sebagai alat untuk mengkaji naratif sastra, khususnya naratif fiksi.

Berdasarkan tiga tingkatan naratif tersebut, Genette (1980: 31) mengemukakan tiga kategori struktur naratif sebagai dasar pemikirannya, yaitu tense, mood, dan voice. Dalam pembahasan bukunya, selanjutnya Genette membagi unsur tense menjadi tiga bagian, yaitu order, duration, dan frequency). Dengan demikian, pokok bahasan struktur naratif/penceritaan Gérard Genette (1980) terdiri atas lima kategori utama, yaitu (1) urutan naratif (order), (2) durasi naratif (duration), (3) frekuensi naratif (frequency), (4) modus naratif (mood), dan (5) suara naratif (voice). Urutan naratif (order) mengacu pada hubungan antara urutan kejadian dalam cerita dan pengaturannya dalam cerita. Durasi naratif (duration) menggambarkan perbedaan antara waktu yang sebenarnya dari suatu peristiwa (story time) dan waktu yang dibutuhkan narator untuk menceritakan peristiwa tersebut (narrative time). Frekuensi naratif (frequency) berhubungan dengan keseringan sebuah peristiwa terjadi dalam cerita dan seberapa sering peristiwa tersebut disebutkan dalam cerita. Modus naratif (mood) yang memfokuskan pada konsep 'jarak' (distance) dan 'perspektif' (perspective) atau fokalisasi (focalization). Sementara itu, suara naratif (voice) berhubungan dengan siapa yang bercerita, dan dari mana ia bercerita. Setiap struktur tersebut memiliki bagian-bagian yang menjadi bahan analisis dalam sebuah wacana naratif. Kelima struktur naratif dan bagian-bagiannya dapat dilihat pada gambar berikut ini. 


$\begin{array}{ll}\text { 1. Urutan } & \text { a. Akroni } \\ \text { Naratif (Order) } & \text { b. Anakroni } \\ & \text { - prolepsis } \\ & \text { - analepsis }\end{array}$

2. Durasi Naratif a. jeda

$\begin{array}{ll}\text { (Duration) } & \begin{array}{l}\text { b. adegan } \\ \text { c. ringkasan } \\ \text { d. ellipsis }\end{array} \\ \text { 3. Frekuensi } & \begin{array}{l}\text { a. tunggal } \\ \text { Naratif }\end{array} \\ \text { b. anaforis } \\ \text { Frequency) } & \text { c. pengulangan } \\ & \text { d. iterative }\end{array}$

4. Modus Fokalisasi

Naratif (Mood) a. fokalisasi nol

b. fokalisasi internal

c. fokalisasi eksternal

5. Suara Naratif a. waktu menceritakan

(Voice) - masa lampau

- prediktif

- masa kini

- gabungan

b. person

- heterodiegetik

- homodiegetik

c. tingkatan naratif

- intradiegetik

- extradiegetik

- hipodiegetik/

Metadiegetik

\section{Urutan Naratif (Order)}

Pemahaman terhadap waktu cerita (story time) dan waktu naratif atau waktu penceritaan (narrative time) merupakan konsep dasar Genette dalam memahami waktu dalam wacana naratif (1980: 33). Waktu cerita (story time) merujuk pada waktu sebuah peristiwa yang terjadi secara nyata, sedangkan waktu penceritaan (narrative time) merujuk pada cara penyajian waktu cerita tersebut dalam sebuah teks wacana naratif. Waktu cerita biasanya ditandai dengan satuan detik, menit, jam, hari, bulan, dan tahun, sedangkan waktu naratif biasanya diukur dalam baris dan dalam halaman (Genette, 1980: 87--88). Hubungan antara keduanya (waktu cerita dan waktu penceritaan) menciptakan struktur penceritaan yang disebut order atau urutan naratif. Urutan naratif (order) mengacu pada hubungan antara urutan kejadian dalam cerita dan pengaturan kejadian tersebut dalam sebuah naratif. Urutan naratif (order) terdiri atas dua jenis.

1) Akroni (achrony), yaitu jika antara waktu cerita dan waktu penceritaan berjalan normal, bersama-sama, dan sejajar.

2) Anakroni (anachrony), yaitu jika antara waktu cerita dan waktu penceritaan tidak terjalin secara normal, tidak sejajar, atau saling mendahului.

Anachrony dibagi menjadi dua jenis, yaitu:

a. Prolepsis atau flashforward, terjadi jika wacana cerita melompat ke depan menuju peristiwa-peristiwa setelah peristiwa-peristiwa menengah. Todorov (1985:28) menyebutnya dengan istilah prospeksi.

b. Analepsis atau flashback, jika terjadi pemutusan arus cerita untuk mengingat kembali peristiwa-peristiwa sebelumnya. Todorov (1985:28) menyebutnya dengan istilah retrospeksi).

Genette (seperti dikutip oleh Chatman, 1980:65), membedakan tiga kemungkinan terjadinya anakroni di dalam sebuah jalannya cerita, yaitu eksternal, internal, dan campuran. Jika peristiwa awal dan peristiwa akhir terjadi sebelum peristiwa masa kini, disebut anakroni eksternal (external anachrony). Jika peristiwa-peristiwa awal terjadi setelah peristiwa masa kini, disebut anakroni internal (internal anachrony). Terakhir, jika peristiwa awal terjadi sebelum peristiwa masa kini, sedangkan peristiwa akhir terjadi setelah peristiwa masa kini, itulah yang disebut anakroni campuran (mixed anachorony).

\section{Durasi Naratif (Duration)}


Durasi naratif (duration) menggambarkan perbedaan antara waktu yang sebenarnya dari suatu peristiwa (story time) disingkat (ST) dan waktu yang dibutuhkan narator untuk menceritakan peristiwa tersebut (narrative time) disingkat (NT). Genette (1980: 95) membedakan empat gerakan naratif, yaitu jeda (pause), adegan (scene), ringkasan (summary), dan ellipsis (ellipsis). Genette meringkas empat gerakan naratif tersebut sebagai berikut.

Jeda $\quad$ : $\mathrm{NT}=\mathrm{n}, \mathrm{ST}=0$. Jadi: $\mathrm{NT}>$ ST

Adegan : NT=ST

Ringkasan : NT < ST

Elipsis : $\mathrm{NT}=0, \mathrm{ST}=\mathrm{n}$. Jadi: $\mathrm{NT}<\mathrm{ST}$.

1) Jeda (pause), terjadi jika waktu cerita terputus untuk membuat ruang khusus, sementara masih ada teks naratif. Jadi, waktu naratif memiliki posisi dominan daripada waktu cerita.

2) Adegan (scene), terjadi jika waktu naratif sesuai dengan waktu cerita. Dialog adalah contoh yang baik dari ini.

3) Ringkasan (summary), terjadi jika beberapa bagian dari peristiwa cerita (waktu cerita) diringkas dalam penceritaannya (waktu naratif), sehingga menciptakan percepatan. Dalam hal ini, waktu naratif lebih pendek daripada waktu cerita.

4) Elipsis (ellipsis), terjadi jika wacana naratif berhenti, meskipun waktu cerita terus berlalu. Jadi, waktu cerita lebih banyak daripada waktu naratif.

\section{Frekuensi Naratif (Frequency)}

Frekuensi naratif adalah hubungan keseringan (atau sederhananya pengulangan) antara naratif dengan diegesis. Frekuensi berhubungan dengan kekerapan atau keseringan sebuah peristiwa terjadi dalam tindakan, dan beberapa kali peristiwa disebutkan dalam teks. Genette (1980: 114--116) menyebutkan empat jenis frekuensi naratif sebagai berikut.
1) Representasi tunggal (singulative representation), adalah penceritaan sekaliapa yang terjadi sekali $(1 N / 1 S)$. Contoh: "Kemarin, saya tidur lebih awal."

2) Representasi anaforis (anaphoric representation), penceritaan beberapa kali apa yang terjadi beberapa kali $(\mathrm{n} N / \mathrm{n} S)$.

Contoh: "Senin, saya tidur lebih awal, Selasa saya tidur lebih awal, Rabu saya tidur lebih awal, dll."

3) Representasi pengulangan (repeating representation), yaitu menceritakan beberapa kaliapa yang terjadi sekali $(\mathrm{n} N / 1 S)$.

Contoh: "Kemarin saya tidur lebih awal, kemarin saya tidur lebih awal, kemarin saya tidur lebih awal, dll."

4) Representasi iteratif (iterative representation), adalah penceritaan satu waktu (atau lebih tepatnya: pada satu waktu) apa yang terjadi beberapa $\operatorname{kali}(1 N / \mathrm{n} S)$.

Contoh: "Senin saya pergi tidur lebih awal, Selasa, dll."

\section{Modus Naratif (Mood)}

Modus naratif berkaitan dengan kedudukan atau posisi pengarang, narator, dan tokoh dalam sebuah cerita. Modus memfokuskan pengamatan pada cara pengaturan pengarang dalam menampilkan narator dalam cerita. Apakah narator menjadi tokoh terpenting yang mengisahkan cerita, atau justru berada di luar cerita. Dalam hal ini, Genette (1980: 186) membagi kedudukan narator menjadi empat jenis berikut ini.

1) Narator sebagai tokoh dalam cerita; analisis internal peristiwa: narator menjadi tokoh utama yang mengisahkan cerita.

2) Narator sebagai tokoh dalam cerita; observasi di luar peristiwa: narator menjadi tokoh bawahan yang mengisahkan tokoh utama cerita.

3) Narator bukan tokoh dalam cerita; analisis internal peristiwa: pengarang 
mahatahu atau analitis mengisahkan cerita.

4) Narator bukan tokoh dalam cerita; observasi di luar peristiwa: pengarang mengisahkan ceritanya sebagai pengamat (observer).

Selanjutnya, Genette (1980:189190) memperkenalkan istilah fokalisasi (focalization) sebagai pengganti istilah perspektif (perspective) dan sudut pandang (point of view). Konsep fokalisasi ini digunakan untuk melihat posisi narator dalam cerita. Fokalisasi berkaitan dengan pertanyaan, "who is the character whose point of view orients the narrative perspective?"

Genette membagi teknik fokalisasi naratif menjadi tiga kategori, yaitu fokalisasi nol (zero focalization) atau naratif yang tidak berfokal (nonfocalized narrative), fokalisasi internal (internal focalization), dan fokalisasi eksternal (external focalization).

1) Fokalisasi nol (zero focalization) atau naratif yang tidak berfokal (nonfocalized narrative) adalah teknik fokalisasi naratif yang naratornya mengetahui lebih daripada tokoh (character). Dengan kalimat lain, narator mengatakan lebih dari apa yang diketahui oleh satu tokoh. Pouillon menyebutnya dengan istilah 'visi dari belakang' (vision from behind), sementara Todorov melambangkannya dengan rumus Narrator $>$ Character. Narator dapat saja mengetahui berbagai fakta tentang beberapa tokoh, bentuk fisik, gerakan, cara berpikir, hingga perasaan mereka. Teknik fokalisasi nol ini identik dengan teknik narator mahatahu.

2) Fokalisasi internal (internal focalization) yaitu narator hanya mengatakan apa yang diketahui oleh tokoh. Pouillon menyebutnya 'visi bersama' (vision with), sementara Todorov melambangkannnya dengan Narrator $=$ Character .
Fokalisasi internal dapat dikelompokkan menjadi tiga jenis, yaitu:
a. Fokalisasi tetap (fixed focalization), yaitu narasi dikisahkan oleh satu tokoh dari posisi yang tetap.

b. Fokalisasi bervariasi (variable focalization), yaitu narasi dikisahkan dari beberapa tokoh secara bergantian.

c. Fokalisasi jamak (multiple focalization), yaitu pengisahan sebuah peristiwa dari sudut pandang beberapa tokoh.

3) Fokalisasi eksternal (external focalization) yaitu narator mengatakan lebih sedikit daripada yang diketahui oleh tokoh. Pouillon menyebutnya 'visi dari luar', sementara Todorov melambangkannya dengan Narrator $<$ Character. Pada fokalisasi eksternal ini, narator hanya bertindak seperti pengamat dan melaporkan setiap tindakan tokoh-tokohnya dari luar, dan dia tidak dapat menebak pikiran mereka.

\section{Suara Naratif (Voice)}

Suara naratif (voice) berhubungan dengan siapa yang bercerita, dan dari mana ia bercerita. Suara naratif memfokuskan kajian pada time of narrating (waktu menceritakan), person (pelaku), dan narrative level (tingkatan naratif). Berikut pokok pemikiran Genette tentang tiga fokus kajian suara naratif.

Time of narrating atau waktu menceritakan merupakan posisi narator dalam menggambarkan waktu di dalam ceritanya. Genette (1980: 217) membagi empat tipe waktu menceritakan, yaitu subsequent, prior, simultaneous, dan interpolated.

1) Subsequent atau naratif masa lampau, yaitu narator menceritakan peristiwa yang terjadi pada beberapa waktu yang telah berlalu.

2) Prior atau naratif prediktif, yaitu narator bercerita tentang apa yang 
terjadi pada masa yang akan datang. Jenis ini semacam mimpi atau ramalan.

3) Simultaneous atau naratif masa kini, yaitu narator bercerita tentang peristiwa dan aksi yang terjadi pada masa sekarang.

4) Interpolated naratif yang merupakan tindak menceritakan yang kompleks, yaitu narator menggabungkan peristiwa yang sedang dan akan terjadi.

Aspek person berkaitan dengan siapa yang berkisah dalam cerita tersebut. Dalam hal ini, Genette (1980: 244--245) membagi dua tipe narator, yaitu heterodiegetic dan homodiegetic.

1) Narator heterodiegetic merupakan jenis naratif yang naratornya tidak hadir dalam cerita yang dikisahkannya.

2) Narator homodiegetic merupakan naratif yang naratornya hadir sebagai tokoh dalam cerita yang dikisahkannya. Jika narator homodiegetic menjadi tokoh utama atau tokoh protagonis dalam cerita, ia disebut sebagai narator autodiegetic.

Aspek tingkat naratif (narrative level) berkaitan dengan dari mana narator mengisahkan ceritanya. Genette (1980: 248) melihat hubungan antara tingkat naratif (ekstradiegetik atau intradiegetik) dengan tipe narator (heterodiegetik atau homodiegetik), ke dalam empat tipe dasar status narator.

1) Paradigma ekstradiegetikheterodiegetik, yaitu narator di tingkat pertama yang bercerita, namun ia sendiri tidak hadir dalam ceritanya.

2) Paradigma ekstradiegetikhomodiegetik, yaitu narator di tingkat pertama yang menceritakan kisahnya sendiri.

3) Paradigma intradiegetikheterodiegetik, yaitu seorang narator dalam derajat kedua yang menceritakan kisah-kisahnya, namun ia tidak hadir dalam ceritanya.
4) Paradigma intradiegetikhomodiegetik, yaitu narator dalam derajat kedua yang menceritakan kisahnya sendiri.

\section{PENUTUP}

Genette menekankan penggunaan tiga istilah yang berbeda tentang naratif, yaitu (1)story 'cerita' sebagai konten narasi, (2) narrative 'naratif atau penceritaan' yaitu wacana atau teks naratif itu sendiri, dan (3) narrating 'menceritakan' sebagai aksi atau tindakan memproduksi naratif. Dari ketiga istilah tersebut, yang menjadi pokok kajian Genette adalah pada makna kedua, yaitu pada tingkat wacana naratif (narrative discourse). Tingkat wacana naratif menjadi pokok kajian Genette karena mempunyai cakupan yang lebih luas sebagai analisis tekstual (textual analysis) sehingga tepat dijadikan sebagai alat untuk mengkaji naratif sastra, khususnya naratif fiksi.

Struktur naratif, menurut Genette, terdiri atas lima kategori utama, yaitu (1) urutan naratif (order), (2) durasi naratif (duration), (3) frekuensi naratif (frequency), (4) modus naratif (mood), dan (5) suara naratif (voice). Pertama, urutan naratif (order) mengacu pada hubungan antara urutan kejadian dalam cerita dan pengaturannya dalam cerita. Urutan penyajian cerita dapat secara kronologis atau berurutan maju (prolepsis), dan dapat pula secara non-kronologis atau kilas balik flashback (analepsis). Kedua, durasi naratif (duration) yang menggambarkan perbedaan antara waktu yang sebenarnya dari suatu peristiwa (discourse time) dan waktu yang dibutuhkan narator untuk menceritakan peristiwa tersebut (narrative time). Ketiga, frekuensi naratif (frequency) berhubungan dengan keseringan sebuah peristiwa terjadi dalam cerita dan seberapa sering peristiwa tersebut disebutkan dalam cerita. Keempat, modus naratif (mood) 
yang memfokuskan pada konsep 'jarak' (distance) dan 'perspektif' (perspective) atau fokalisasi (focalization). Kelima, suara naratif (voice) berhubungan dengan siapa yang bercerita, dan dari mana ia bercerita.

\section{DAFTAR PUSTAKA}

Abbott, H. Porter. (200)2. The Cambridge Introduction of Narrative. Australia: Cambridge University Press.

Altman, Rick. (2008). A Theory of Narrative. Columbia University Press Bertens, Hans.( 2014). Literary Theory: The Basic. New York :Routledge

Bortolussi, Marisa dan Peter Dixon. (2003). Psychonarratology: Foundations for the Empirical Study of Literary Response. New York: Cambridge University Press.

Chatman, Seymour. (1980). Story and Discourse. Narrative Structure in Fiction and Film. Ithaca and London: Cornell University Press.

Currie, Gregory. (2010). Narratives and Narrators: A Philosophy of Stories.

Oxford: Oxford University Press.

Fludernik, Monika. (2009). An Introduction to Narratology. London and New York: Routledge.

Genette, Gérard. (1980). Narrative Discourse: An Essay in Method. Translated by Jane E. Lewin. New York: Cornell University Press.

Jannidis, Fotis. (2003). Narratology and the narrative. Dalam Tom Kindt and HansHarald Müller (Ed), What is narratology? Questions and answers regarding the status of a theory. Berlin: Walter de Gruyter. Prince, Gerald. ( 1982). Narratology: The Form and Functioning of Narrative. Amsterdam: Mouton Publishers.
Schmid, Wolf. 2010). Narratology: An Introduction. New York: De Gruyter.

Todorov, Zvetan. (1985). Tata Sastra. Diterjemahkan oleh Okke Zaimar, dkk. Jakarta: Djambatan 